\title{
A Comparative Study of Phytochemical Profile of Different Solvents' Effects on Total Phenolic Content and Antioxidant Activities of Various Parts of Halimium halimifolium
}

\author{
Sabah El gamouz (D), Omayma Bouzekri, Mostafa Elidrissi, Ali Amechrouq, \\ and M'bark Choukrad \\ Laboratory of Natural Substances and Organic Chemistry, Faculty of Sciences, Moulay Ismail University of Meknes, \\ BP 11201 Zitoune, Meknes, Morocco \\ Correspondence should be addressed to Sabah El gamouz; elgamouzsabah@gmail.com
}

Received 19 June 2021; Revised 22 September 2021; Accepted 10 January 2022; Published 1 February 2022

Academic Editor: Claudia Crestini

Copyright (C) 2022 Sabah El gamouz et al. This is an open access article distributed under the Creative Commons Attribution License, which permits unrestricted use, distribution, and reproduction in any medium, provided the original work is properly cited.

\begin{abstract}
In the present work, the extraction and the variation of total phenolic and the flavonoid content of the Halimium halimifolium plant (the leaves and the stems) harvested from Morocco have been studied. It explores extracting the essential oil of this plant and analyzing its chemical composition by the gas chromatography-mass spectrometry (GC/MS). Interesting results have been obtained, in particular, the presence of 26 compounds where the major one is (+)-2-Bornanone (38.26\%) followed by Eucalyptol $(27.74 \%)$. This essential oil proves great antioxidant capacities which is measured with the total antioxidant activity (TAC) and the organic chemical compound 2,2-diphenyl-1-picrylhydrazyl (DPPH) assays. On the other hand, using solvents with different polarities (the hexane, the dichloromethane, the ethyl acetate, the ethanol, and the water), the quantifying of the total phenolic and the flavonoid content for different crude extracts of the Halimium halimifolium was done. The results show simultaneous increasing in the total phenolic content of the crude extract and the solvent polarity.
\end{abstract}

\section{Introduction}

Since a long time, the plants were used for the traditional medicine due to their therapeutic effects against various diseases. The products of the plant derivatives were also utilized due to their antioxidant properties, low toxicity, and strong bioactivities [1]. Recently, scientific researches have started looking for new natural antioxidants which are able to donate protons to postpone the increasing of the free radical and also postpone the formation of the species of the reactive oxygen in the health. These reactive species cause the oxidative stress in the systemic level and increase the health problems such as the cancer and the cardiovascular diseases [2]. Some crude extracts of the aromatic plants are rich in the total phenolic contents. They revealed a significant total antioxidant activity that could be used as a potential natural source of the antioxidants to prevent the oxidative stress [3]. In this paper, we are interested in Cistaceae family, in particular, the Halimium halimifolium harvested from Morocco, which has not been yet studied. It is a Mediterranean medicinal plant [4] used as stomach treatment and to eject intestinal gas [5]. This plant was selected due to its multitraditional uses and the lack of chemical and biological investigations in literature data. Furthermore, the aim of the present work is to highlight the correlation between the total phenolic contents and the antioxidant activities that were achieved by TAC and DPPH assays of different crude extracts from the leaves and the stems of the Halimium halimifolium plant. In addition, we have studied the chemical composition of the essential oil of the Halimium halimifolium and its total antioxidant activities. 


\section{Materials and Methods}

2.1. Vegetal Material. The various parts (leaves and stems) of the Halimium halimifolium were harvested on April 2018 from South East Morocco and the collected samples were identified by Pr. Mohamed IbnTatto. During 15 days, these samples were well dried under the shadow at the room temperature and then reduced to a fine powder separately for the hydrodistillation and the solvents extractions. The vegetal material under study consists of the Halimium halimifolium which belongs to Cistaceae family, Magnoliopsida class, and Halimium type.

2.2. Extraction of Essential Oil. The extraction of the essential oil was executed by hydrodistillation in a Clevenger device. For an hour and a half, three distillations were executed by boiling $100 \mathrm{~g}$ of fresh vegetal material (leaves and stems) with $1 \mathrm{~L}$ of the water in a $2 \mathrm{~L}$ tank $60 \mathrm{~cm}$ high. This tank has an outer column connected to a refrigerant. The obtained essential oil was stocked in a dark place at $4^{\circ} \mathrm{C}$ with the presence of the anhydrous sodium sulphate. Then, it was diluted in the methanol (1\% v/v) before doing CG/SM analysis [6].

2.3. Chemical Composition. The identification of the chemical components was carried out using mass spectrometer interfaced with a gas chromatograph in the common analysis center, Faculty of Sciences, Meknes, Morocco (GC-MS: 7890 B Agilent technologies), equipped with 19091S-433 Agilent fused HP-5MS silica capillary column (5\% phenyl Methylpolysiloxane, $30 \mathrm{~m}, 250 \mu \mathrm{m}$; film thickness $0.25 \mu \mathrm{m}$ ), coupled to mass spectrometer Agilent technologies 5977A MSD (ion source $\beta \gamma^{\circ} \mathrm{C}, 70 \mathrm{ev}$ ). GC oven initial temperature was $70^{\circ} \mathrm{C}$ during $45 \mathrm{~min}$ under the following operation conditions: vector gas: helium. The injector temperature was $250^{\circ} \mathrm{C}$ and split ratio of $80 / 1$ was injected. The helium was used as the carrier gas at $3 \mathrm{~L} / \mathrm{min}$. The identification of the components was done by the comparison of the case registry number (Cas) and MS with the corresponding database (NIST library) and with the mass spectral literature [7].

\subsection{Determination of Physicochemical Indexes}

2.4.1. Physical Characteristics. Density is the relation between the mass of certain oil's volume at $20^{\circ} \mathrm{C}$ and that of the distilled water with the same volume and temperature. It consists of successively weighing a volume equal to the distilled water and the essential oil studied at the temperature $20^{\circ} \mathrm{C}$ by using a pycnometer. It also consists of calculating the density by using the relation expressed in the following equation:

$$
D_{20}=\frac{\left(m_{2}-m_{0}\right)}{\left(m_{1}-m_{0}\right)} .
$$

$m_{0}$ is the mass of the empty pycnometer. $m_{1}$ presents the mass of the pycnometer filled with the distilled water. $m_{2}$ denotes the mass of the pycnometer filled with the studied oil.
2.4.2. Chemical Characteristics. Acid index: the acid indicator is the necessary amount of milligrams of potassium hydroxide $(\mathrm{KOH})$ needed to neutralize the free acids contained in one gram of the essential oil. The weight of the studied oil in an Erlenmeyer is $1 \mathrm{~g}$. Adding $30 \mathrm{ml}$ of the ethanol, the titrating is effectuated with the potassium hydroxide solution $(0.1 \mathrm{~N})$ and some drops of phenolphthalein until obtaining the pink color [8].

The formula of the acid indicator is given in the following equation:

$$
\text { IACID }=M \times V \times \frac{N}{m} .
$$

$M$ is the molar mass expressed in $\mathrm{g} /$ mole of $\mathrm{KOH}$ $(M=56.1 \mathrm{~g} / \mathrm{mole}) . N$ presents the normality of the titrated solution $\mathrm{KOH}(0.1 \mathrm{~N})$. $V$ denotes the volume $(\mathrm{ml})$ of the titrated $\mathrm{KOH} . \mathrm{m}$ is the mass $(\mathrm{g})$ of the taken assay.

2.4.3. Determination of the Saponification Index. It is based on the necessary mass of the potassium hydroxide $(\mathrm{KOH})$ needed to saponify the esters and the fatty acids. It is also needed to neutralize the fatty acids that have not been esterified that exist in $1 \mathrm{~g}$ of the essential oil [8].

$$
\mathrm{Is}=\frac{((\mathrm{VT}-\mathrm{VE}) \times \mathrm{CHCl} \times 56.1)}{m},
$$

where Is is the index of the saponification, VT is the blank's volume $(\mathrm{mL}), \mathrm{VE}$ is the test's volume $(\mathrm{mL}), \mathrm{CHCl}$ is the chloric acid concentration $(\mathrm{mol} / \mathrm{L}), 56.1(\mathrm{~g} / \mathrm{mol})$ is the molar mass of $\mathrm{KOH}$, and $\mathrm{m}$ is the mass of the analyzed essential oil ( $\mathrm{g})$.

2.4.4. Determination of the Ester Index. The ester index is the necessary mass of the potassium hydroxide $\mathrm{KOH}(\mathrm{mg})$ to saponify the esters that has not esterified in $1 \mathrm{~g}$ of the essential oil [8]. It is calculated using the following formula:

Ester index $=$ saponification index - acid index.

\subsection{Preparation of the Extracts}

2.5.1. Extraction by Soxhlet. $30 \mathrm{~g}$ of the leaves and the stems of the Halimium halimifolium were extracted with different pure solvents $(300 \mathrm{~mL})$, the hexane, the dichloromethane, the ethyl acetate, and the ethanol, using the Soxhlet device until the solvent turned colorless again. Then, the mixtures were filtered and the solvents were evaporated by rotary evaporator and finally the yields were calculated [9].

2.5.2. Infusion. The aqueous extract is obtained by adding the boiling distilled water to $30 \mathrm{~g}$ to each part (leaves and stems) of the plant during $6 \mathrm{~h}$. Then, the mixture was filtered and the solvents were also filtered and evaporated.

2.5.3. Extraction Yield. The extraction yield is given in the following equation: 


$$
R \%=\left(\frac{M_{1}}{M_{0}}\right) \times 100 .
$$

$M_{1}$ is the mass of the essential oil or the crude extract ( $\mathrm{g}$ ) and $M_{0}$ is the masse of the vegetal material $(\mathrm{g})$.

2.5.4. Instrument. Using SHIMADZU UV mini- 1240 UV-VIS spectrophotometer, all spectrophotometric data were treated (glass cuvette $(1 \mathrm{~cm} \times 1 \mathrm{~cm} \times 4.5 \mathrm{~cm})$ ).

2.5.5. Statistical Analysis. The results are mentioned as mean \pm standard deviation of three replicates. The statistical analyses were performed using Microsoft Excel followed by one-way ANOVA. Pearson's table of the correlation coefficients was used to determine the interrelationships among the total phenolic content (TPC), the total flavonoid content (TFC), and the antioxidant activities. The values were statistically significant when $P<0.05$.

\subsection{Determination of the Phenolic Compounds Contents}

2.6.1. Total Phenolic Content. The total phenolic content was determined by the Folin-Ciocalteu method [10]. Briefly, $0.3 \mathrm{~mL}$ at $1 \mathrm{mg} / \mathrm{mL}$ of each crude extract was mixed with $1.5 \mathrm{~mL}$ of the Folin-Ciocalteu's reagent and $1.2 \mathrm{~mL}$ of the solution at $7.5 \%$ of sodium carbonate $\left(\mathrm{Na}_{2} \mathrm{CO}_{3}\right)$. The mixture was incubated at the dark for 2 hours. Then, the absorbance was read with spectrophotometer at $765 \mathrm{~nm}$. The TPC was calculated using the regression equation from the calibration curve employing the gallic acid standard. The data are results from three replicates \pm standard deviation. The total phenolic content was expressed in $\mathrm{mg}$ of gallic acid equivalents per gram of the dry weight (mg GAE/g).

2.6.2. Total Flavonoid Content. The total flavonoid content was determined by the technique of Olajire and Azeez [11]. $1 \mathrm{ml}(1 \mathrm{mg} / \mathrm{ml})$ of the solution of each extract was added to $2,4 \mathrm{~mL}$ of the distilled water and $0,3 \mathrm{~mL}$ of $5 \% \mathrm{NaNO}_{2}$ (sodium nitrate). After 5 minutes, we have added $0,3 \mathrm{~mL}$ of $10 \% \mathrm{AlCl}_{3}$.

The mixture was left to stand for 6 minutes and was incubated at the dark. Finally, $1 \mathrm{~mL}$ of $\mathrm{NaOH}$ (sodium hydroxide) ( $1 \mathrm{M}$ ) was added, and this mixture was up to $10 \mathrm{ml}$ with the distilled water. After agitation, the absorbance was read immediately at $510 \mathrm{~nm}$ with a spectrophotometer. After three replicates, the data are expressed in terms of milligram (equivalent of quercetin per gram of crude extract (mg QE/g) \pm standard deviation). These results were calculated from the calibration of the quercetin.

2.7. Evaluation of the Antioxidant Activity. The antioxidant activity has been studied by two different methods. The first one measures the totality of this activity using the phosphomolybdenum method, while the second one measures the extract's capacity of the trapping radicals using the most stable radical which is DPPH (2,2-diphenyl-1-picryl- hydrazyl). Ascorbic acid (AA) was used as the standard and the results were expressed in milligram equivalent of AA per gram of crude extract $(\mathrm{mg} \mathrm{AA} / \mathrm{g}) \pm$ standard deviation. The values are the average of three replicates.

2.7.1. Total Antioxidant Activity (TAC). This procedure is a spectroscopic method for determining overall antioxidant activity. This method reduces $\mathrm{Mo}(\mathrm{VI})$ (colorless solution) in an acid environment to $\mathrm{Mo}(\mathrm{V})$ (green color). This activity was calculated by using the method described by Prieto et al. [12] and Nur Alam [13]. Briefly, 0,1 ml of the sample $(1 \mathrm{mg} / \mathrm{ml})$ is mixed with $1 \mathrm{ml}$ of the reagents $(0.6 \mathrm{M}$ sulfuric acid, $28 \mathrm{mM}$ sodium phosphate, and $4 \mathrm{mM}$ of ammonium molybdenum). The tube was incubated at $95^{\circ} \mathrm{C}$ during $90 \mathrm{~min}$. After cooling, the solution's absorbance was measured at $695 \mathrm{~nm}$ [13]. The values of TAC are results from three replicates \pm standard deviation. TAC was expressed in $\mathrm{mg}$ of ascorbic acid equivalents per gram of crude extract (mg AA/g).

2.7.2. DPPH Free Radical Scavenging Activity. The hydrogen atom donation ability of different crude extracts and essential oil of Halimium halimifolium was measured by 2,2-diphenyl-1-picryl-hydrazyl (DPPH) free radical scavenging assay [14]. In this test, the purple DPPH is reduced to a yellow component color which is 2,2diphenyl-1-picryl-hydrazine. The color's intensity is inversely proportional to the reduced capacity of the present antioxidants [15]. The reaction was realized in a total volume of $2 \mathrm{ml}$ containing $1950 \mu \mathrm{L}$ of DPPH $(0.024 \mathrm{~g} / \mathrm{L})$. The samples were incubated during 30 minutes and the absorbance was measured at $515 \mathrm{~nm}$ [16]. The inhibition \% is calculated as follows: inhibition $\%=[(\mathrm{A}$ blank- $\mathrm{A}$ sample) /A blank] $\times 100$, where "A blank" is the negative control absorbance at $515 \mathrm{~nm}$ and "A sample" denotes the sample absorbance at $515 \mathrm{~nm}$.

The different concentrations of the extract which reduced the DPPH solution allow the calculation of $I C_{50}$. A stronger antioxidant activity is indicated by a low value of $I C_{50}$. The $I C_{50}$ is the corresponding value of the sample's concentration needed to trap 50\% of DPPH in the solution test. The antioxidant capacity was determined from $I C_{50}$ value. The efficient concentration $E C_{50}(\mathrm{mg} / \mathrm{mg}$ of $\mathrm{DPPH})$ was expressed as a concentration of the sample used for the test $(\mathrm{mg} / \mathrm{mL})$ in relation to DPPH initial quantity (mg of $\mathrm{DPPH} / \mathrm{mL}$ of solvent). $E C_{50}=I C_{50} /$ concentration of $\mathrm{DPPH}$. The value of the antiradical power (ARP) was determined as the efficient concentration's inverse value. For this reason, the sample with a lower effective concentration $E C_{50}$ (also lower $I C_{50}$ ) has the higher ARP value. This means that this sample has the greatest antioxidant activity $\left(A R P=100 / E C_{50}\right.$ [17]).

\section{Results and Discussion}

3.1. Extraction of the Essential Oil. After three assays, the extraction of the essential oil of the Halimium halimifolium (leaves and stems) using the Clevenger device shows a yield equal to $1.4 \pm 0.02 \%$. 
3.2. Determination of the Physical-Chemical Characteristics. The results of the obtained physicochemical characteristics of the essential oil are summarized in Table 1. For the chemical constants, the acid indicator (IA) gives an idea about the rate of the free acids. Also, the results of this study show that this indicator remains relatively near to the standards. That is, an IA inferior to 2 proves a good conservation of essence (low quantity of the free acids). On the contrary, an IA superior to 2 explains the degradation of the essential oil (esters' hydrolysis) during its conservation which can damage its chemical composition [18]. The values were the mean of three replicates \pm standard deviation.

The determination of the physicochemical properties is an essential step, but it remains insufficient to define the essential oil. Therefore, this remains essential to determine the chromatographic profile of the aromatic essence.

3.3. Chemical Composition. The analyzing of the essential oil of the Halimium halimifolium by the gas chromatography is paired with the mass spectrum (Table 2). Furthermore, the major compounds were (+)-2-Bornanone (38.26\%) and Eucalyptol (27.74\%).

3.4. Extraction Yields of the Halimium halimifolium. Using different solvents, the results of yields' extractions (Table 3$)$ were significantly different $(P<0.05)$. Also, the leaves and the stems of the Halimium halimifolium show simultaneous increasing in the extractions' yields and the solvents' polarities. This result is proved by yields' values, in which the water had the highest average of $17.95 \%$ followed by the ethanol, the ethyl acetate, the dichloromethane, and the hexane that showed the lowest yield of the extraction with $3.26 \%$. The leaves revealed the highest yields' extraction through different solvents.

Those crude extracts revealed different aspects that were presented in Table 4.

3.5. Determination of the Total Phenolic (TPC) and the Flavonoid (TFC) Content. TPC and TFC were determined by Folin-Ciocalteu's method and Olajire and Azeez [11] protocol, respectively. The results of TPC and TFC of the crude extract were expressed by $\mathrm{mg} \mathrm{GAE} / \mathrm{g}$ and $\mathrm{mg} \mathrm{QE} / \mathrm{g}$; also the results of the calibration curves of gallic acid and quercetin are presented in Figures 1 and 2, respectively. Phenolic compounds are secondary metabolites ubiquitous in plants. They are known by possessing antioxidant activities. It is probably that the activity of these crude extracts is due to these compounds $[19,20]$. Meanwhile, flavonoids are secondary metabolites of plants (Vitamin P). These metabolites produce pigments which are responsible for plants' color. Furthermore, flavonoids are ingested easily in the human body. They also seem to have anti-inflammatory, antiallergic, and anticancer activities [21]. The results obtained in this study showed a significant level of phenolic compounds and flavonoid in aqueous and ethanol extracts of the leaves and stems of Halimium halimifolium (Table 5). This distinction is due to the richness or the lack of some content. It could be attributed to the used solvents during the extraction [22, 23]. Between each concentration of TPC and TFC of all crude extracts, a significant difference was shown $(P<0.05)$. Those results proved that the Halimium halimifolium is rich in the phenolic and the flavonoid compounds.

The results revealed that the concentration of phenolic and flavonoid compounds in leaves and stems increases when the solvent's extraction polarity increases too. Precisely, the concentrations of the phenolic compounds are varied from $347.905 \pm 1.05$ to $64.11 \pm 0.45 \mathrm{mg}$ of GAE/g of the crude extract for the leaves and from $324.537 \pm 1.07$ to $98.958 \pm 0.41 \mathrm{mg}$ of $\mathrm{GAE} / \mathrm{g}$ of crude extract for the stems, whereas the flavonoid appears in the leaves from $230.087 \pm 1.17$ to $29.435 \pm 0.36 \mathrm{mg}$ of $\mathrm{QE} / \mathrm{g}$ of the crude extract and from $200.956 \pm 0.93$ to $51.174 \pm 0.25 \mathrm{mg}$ of QE /g of the crude extract for the stems. For each part of Halimium halimifolium, the highest concentrations of the phenolic and flavonoid compounds are showed by the aqueous extracts followed by the ethanol, the ethyl acetate, the dichloromethane, and then the hexane. Otherwise, polar extracts (water, ethanol, and ethyl acetate) show more flavonoids and phenolic compounds than anapolar extracts (hexane). Also, the flavonoid appears, for each solvent, in the leaves with high quantities more than the stems except for hexane, where the stems are rich in the flavonoid compared to the leaves. According to the results, in each part of Halimium halimifolium, the water and the ethanol, respectively, had the greatest capabilities to extract the total phenolic compounds because of having the two highest polarities, followed by the ethyl acetate dichloromethane, while the hexane shows the lowest capacity to extract the phenolic compounds and the lowest polarity. The Halimium halimifolium's leaves harvested from Tunisia were studied by Rebaya et al. [24] using the same solvents as this study (water, ethanol, ethyl acetate, and dichloromethane), and the results of Halimium halimifolium's leaves harvested from Morocco revealed a higher amount of total phenolic and flavonoid content than Tunisian Halimium halimifolium. This dissimilarity of results could be related to the harvested regions' groundwater, climatic, or population differences. These results indicate the influence of the extraction solvent on the total content of the extracted phenolic compounds. These results are similar to those reported by Alaliab et al. [25] that showed similar results of the Helianthemum lippii L. (Cistaceae). It is concluded that the crude extract affluence of the phenolic content increases once the polarity of the solvent extraction used increases too. Several studies as in $[3,26]$ approve the fact that the phenolic compounds' extraction from the plant is more efficient with the higher polar solvent [27].

\subsection{Antioxidant Activities of the Halimium halimifolium}

3.6.1. Total Antioxidant Activity (TAC). The valuation of the total antioxidant activity of the Halimium halimifolium's crude extracts from the leaves and the stems using the phosphomolybdenum process is expressed in $\mathrm{mg} \mathrm{AA} / \mathrm{g}$ of crude extract and shows a significant difference $(P<0.05)$ (Table 6). The aqueous extract of Halimium halimifolium 
TABLE 1: The physicochemical indexes of the essential oil of the Halimium halimifolium.

\begin{tabular}{lr}
\hline Property & Values \\
\hline Density at $20^{\circ} \mathrm{C}$ & $0.84 \pm 0.01$ \\
Acid index & $2.00 \pm 0.10$ \\
Saponification index & $13.24 \pm 0.4$ \\
Ester index & $11.23 \pm 0.3$ \\
\hline
\end{tabular}

TABLE 2: Essential oil components of the Halimium halimifolium.

\begin{tabular}{|c|c|c|c|c|c|}
\hline $\mathrm{N}$ & Components & Chemical formula & $\mathrm{RT}$ & RI & $\%$ Area \\
\hline \multicolumn{6}{|c|}{ Monoterpenes Hydrocarbons } \\
\hline 1 & $\alpha$-Pinene & $\mathrm{C} 10 \mathrm{H} 16$ & 7.84 & 931 & 0.24 \\
\hline 2 & Camphene & $\mathrm{C} 10 \mathrm{H} 16$ & 8.24 & 940 & 10.72 \\
\hline 3 & $\beta$-Pinene & $\mathrm{C} 10 \mathrm{H} 16$ & 9.16 & 968 & 1.43 \\
\hline 4 & O-Cymene & $\mathrm{C} 10 \mathrm{H} 14$ & 10.78 & 1006 & 2.47 \\
\hline \multicolumn{6}{|c|}{ Oxygenated monoterpenes } \\
\hline 5 & Eucalyptol & $\mathrm{C} 10 \mathrm{H} 18 \mathrm{O}$ & 11.06 & 1224 & 27.74 \\
\hline 6 & Linalool & $\mathrm{C} 10 \mathrm{H} 18 \mathrm{O}$ & 13.64 & 1083 & 1.36 \\
\hline 7 & $(+)$-2-Bornanone & $\mathrm{C} 10 \mathrm{H} 16 \mathrm{O}$ & 14.58 & 1120 & 38.26 \\
\hline 8 & Isopinocarveol & $\mathrm{C} 10 \mathrm{H} 16 \mathrm{O}$ & 14.65 & 1139 & 1.01 \\
\hline 9 & trans-Verbenol & $\mathrm{C} 10 \mathrm{H} 16 \mathrm{O}$ & 14.90 & 1144 & 0.26 \\
\hline 10 & Pinocarvone & $\mathrm{C} 10 \mathrm{H} 14 \mathrm{O}$ & 15.14 & 1163 & 0.48 \\
\hline 11 & Isoborneol & $\mathrm{C} 10 \mathrm{H} 18 \mathrm{O}$ & 15.58 & 1153 & 2.12 \\
\hline 12 & p-Cymen-8-ol & $\mathrm{C} 10 \mathrm{H} 14 \mathrm{O}$ & 16.13 & 1183 & 0.17 \\
\hline 13 & Myrtenal & $\mathrm{C} 10 \mathrm{H} 14 \mathrm{O}$ & 16.23 & 1193 & 1.15 \\
\hline 14 & $\alpha$-Terpineol & $\mathrm{C} 10 \mathrm{H} 18 \mathrm{O}$ & 16.48 & 1188 & 0.79 \\
\hline 15 & Carvacrol & $\mathrm{C} 10 \mathrm{H} 14 \mathrm{O}$ & 20.39 & 1298 & 0.38 \\
\hline \multicolumn{6}{|c|}{ Sesquiterpenes } \\
\hline 16 & $\gamma$-Muurolene & $\mathrm{C} 15 \mathrm{H} 24$ & 26.03 & 1477 & 0.24 \\
\hline 17 & $\alpha$-Muurolene & $\mathrm{C} 15 \mathrm{H} 24$ & 26.75 & 1484 & 0.25 \\
\hline 18 & $\gamma$-Cadinene & $\mathrm{C} 15 \mathrm{H} 24$ & 27.08 & 1494 & 1.74 \\
\hline 19 & (-)-Calamenene & $\mathrm{C} 15 \mathrm{H} 22$ & 27.19 & 1510 & 0.64 \\
\hline 20 & Cadalene & $\mathrm{C} 15 \mathrm{H} 18$ & 31.24 & 1654 & 1.87 \\
\hline \multicolumn{6}{|c|}{ Oxygenated Sesquiterpenes } \\
\hline 21 & (+)-Spatulenol & $\mathrm{C} 15 \mathrm{H} 24 \mathrm{O}$ & 28.63 & 1576 & 0.65 \\
\hline 22 & (+)-Viridiflorol & $\mathrm{C} 15 \mathrm{H} 26 \mathrm{O}$ & 29.10 & 1590 & 0.70 \\
\hline 23 & Junenol & $\mathrm{C} 15 \mathrm{H} 26 \mathrm{O}$ & 30.16 & 1622 & 0.73 \\
\hline 24 & $\tau$-Cadinol & $\mathrm{C} 15 \mathrm{H} 26 \mathrm{O}$ & 30.47 & 1633 & 1.61 \\
\hline 25 & $\beta$-Eudesmol & $\mathrm{C} 15 \mathrm{H} 26 \mathrm{O}$ & 30.60 & 1642 & 0.61 \\
\hline 26 & $\alpha$-Cadinol & $\mathrm{C} 15 \mathrm{H} 26 \mathrm{O}$ & 30.80 & 2211 & 0.8 \\
\hline \multicolumn{6}{|c|}{ Monoterpenes Hydrocarbons 14.86\% } \\
\hline \multicolumn{6}{|c|}{ Oxygenated monoterpenes $73.72 \%$} \\
\hline \multicolumn{6}{|c|}{ Sesquiterpenes $3.74 \%$} \\
\hline \multicolumn{6}{|c|}{ Oxygenated Sesquiterpenes $5.1 \%$} \\
\hline & \%) $97.42 \%$ & & & & \\
\hline
\end{tabular}

TR: time retention. RI: Kovats retention index.

TABLE 3: Yields (\%) of crudes' extractions of Halimium halimifolium's different parts.

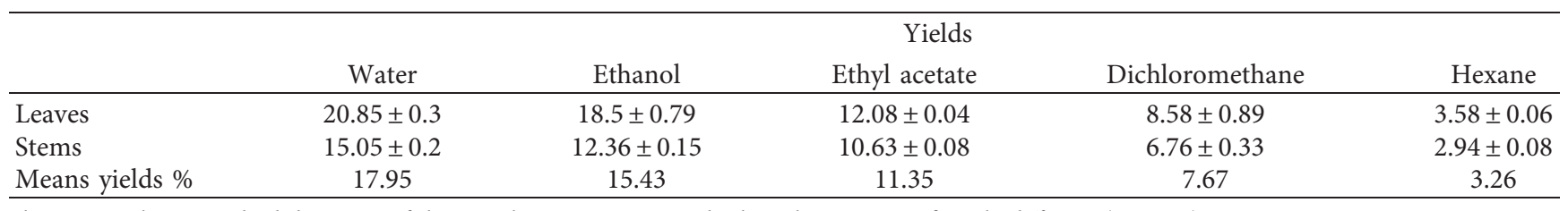

The mean value \pm standard deviation of three replicates is mentioned. The values are significantly different $(P<0.05)$. 
TABLE 4: The aspects of crude extract.

\begin{tabular}{lcc}
\hline Solvent & Leaves & Stems \\
\hline Hexane & Pasty & Powder \\
Dichloromethane & Solid & Pasty \\
Ethyl acetate & Powder & Powder \\
Ethanol & Solid & Pasty \\
Water & Powder & Solid \\
\hline
\end{tabular}

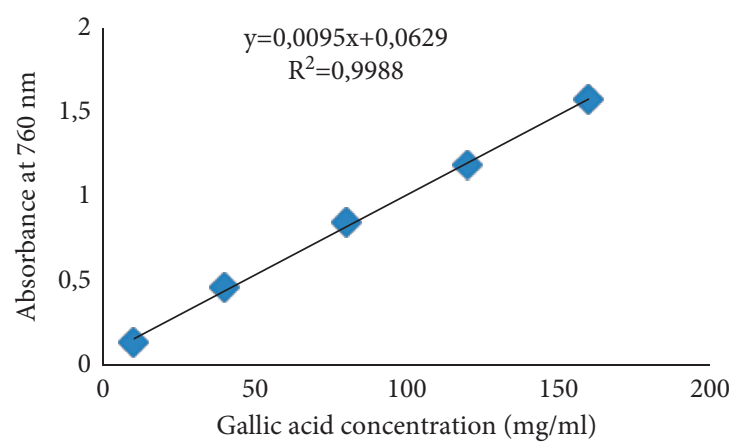

Figure 1: The curve calibration of gallic acid.

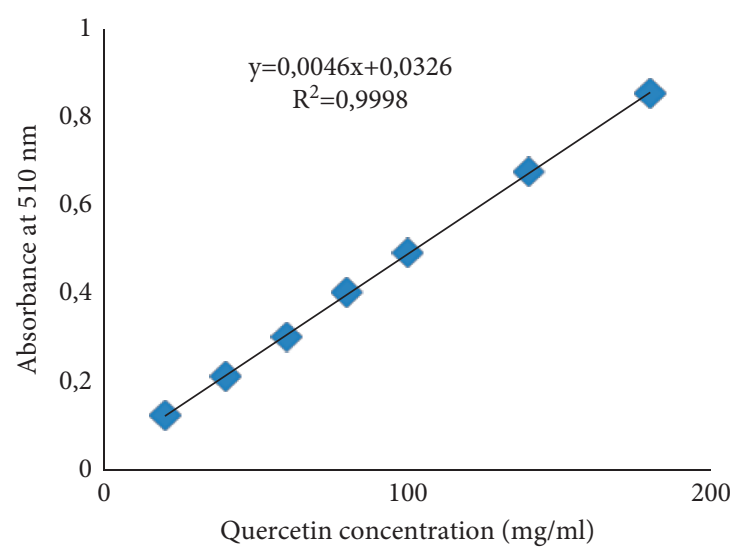

FIgURE 2: The curve calibration of quercetin.

TABLE 5: Total phenolic and flavonoid contents of Halimium halimifolium's leaves and stems extracts.

\begin{tabular}{lcccccc}
\hline Bioactive compounds & Plant's parts & Water & Ethanol & Ethyl acetate & Dichloromethane & Hexane \\
\hline \multirow{2}{*}{ TPC (mg GAE/g) } & Leaves & $347.90 \pm 1.05$ & $241.16 \pm 1.43$ & $192.43 \pm 0.81$ & $96.011 \pm 0.43$ & $64.11 \pm 0.45$ \\
& Stems & $324.63 \pm 1.07$ & $292.85 \pm 0.94$ & $152.22 \pm 0.62$ & $106.91 \pm 0.33$ & $98.95 \pm 0.41$ \\
\multirow{2}{*}{ TFC (mg QE/g) } & Leaves & $230.087 \pm 1.17$ & $165.304 \pm 0.93$ & $94.652 \pm 1.09$ & $71.391 \pm 0.53$ & $29.435 \pm 0.36$ \\
& Stems & $200.956 \pm 0.93$ & $160.522 \pm 1.17$ & $81.174 \pm 0.65$ & $68.565 \pm 0.81$ & $51.174 \pm 0.25$ \\
\hline
\end{tabular}

The mean value \pm standard deviation of the three replicates is mentioned. The values are significantly different $(P<0.05)$.

showed the highest TAC (the leaves with $412.44 \pm 0.82$ and stems with $402.07 \pm 0.66 \mathrm{mg} \mathrm{AA} / \mathrm{g})$.

3.6.2. DPPH Free Radical Scavenging Activity. The Halimium halimifolium's antioxidant activity was measured by scavenging free radical DPPH assay. According to the results presented in Table 6, the aqueous leaves' extract shows the strongest radical scavenging activity which is similar to the quercetin standard (Table 7) with a significant difference $(P<0.05)$. Even the crude extracts show the same significant difference, and the lower antioxidant activity was revealed by the hexane extract from the stems. The mean value \pm standard deviation of the three replicates is mentioned, and the values are significantly different $(P<0.05)$. The greatest TAC and ARP are noted for the aqueous extracts followed, respectively, by the ethanolic, the ethyl acetate, and the dichloromethane crude extracts' leaves and stems, while the hexane crude 
TABLE 6: Total antioxidant capacity (TAC), inhibitory concentration $\left(I C_{50}\right)$, efficient concentration $\left(E C_{50}\right)$, and antiradical power $(A R P)$ of the extracts from Halimium halimifolium's leaves and stems.

\begin{tabular}{|c|c|c|c|c|c|c|}
\hline Bioactive compounds & Plant's part & Water & Ethanol & Ethyl acetate & Dichloromethane & Hexane \\
\hline \multirow{2}{*}{ TAC (mg AA/g) } & Leaves $412.44 \pm 0.82$ & $289.85 \pm 1.15$ & $280.22 \pm 0.25$ & $200.09 \pm 0.25$ & $173.56 \pm 0.25$ & \multirow{2}{*}{ Standard quercetin } \\
\hline & Stems $402.07 \pm 0.66$ & $320.59 \pm 0.94$ & $249.85 \pm 0.63$ & $234.89 \pm 0.90$ & $183.18 \pm 0.57$ & \\
\hline \multirow{2}{*}{$\mathrm{IC}_{50}(\mathrm{mg} / \mathrm{mL})$} & Leaves $0.18 \pm 0.00$ & $0.57 \pm 0.00$ & $0.81 \pm 0.00$ & $1.16 \pm 0.00$ & $1.53 \pm 0.01$ & \multirow{2}{*}{$0.10 \pm 0.00$} \\
\hline & Stems $0.35 \pm 0.00$ & $0.48 \pm 0.00$ & $1.19 \pm 0.01$ & $1.29 \pm 0.00$ & $8.82 \pm 0.05$ & \\
\hline \multirow{2}{*}{$\mathrm{EC}_{50}(\mathrm{mg} / \mathrm{mgDPPH})$} & Leaves $7.66 \pm 0.02$ & $24.07 \pm 0.01$ & $33.88 \pm 0.15$ & $48.54 \pm 0.02$ & $56.27 \pm 0.15$ & \multirow{2}{*}{$0.04 \pm 0.00$} \\
\hline & Stems $14.87 \pm 0.01$ & $20.32 \pm 0.02$ & $49.67 \pm 0.15$ & $54.05 \pm 0.07$ & $367.5 \pm 0.21$ & \\
\hline \multirow{2}{*}{ ARP } & Leaves $13.04 \pm 0.12$ & $4.15 \pm 0.05$ & $2.95 \pm 0.03$ & $2.06 \pm 0.00$ & $1.77 \pm 0.03$ & \multirow{2}{*}{$24.03 \pm 0.00$} \\
\hline & Stems $6.72 \pm 0.05$ & $4.92 \pm 0.04$ & $2.01 \pm 0.01$ & $1.85 \pm 0.00$ & $0.27 \pm 0.01$ & \\
\hline
\end{tabular}

Mean value \pm standard deviation of three replicates is mentioned. Values are significantly different $(P<0.05)$.

TABLE 7: Total antioxidant capacity (TAC), inhibitory concentration $\left(\mathrm{IC}_{50}\right)$, efficient concentration $\left(\mathrm{EC}_{50}\right)$, and antiradical power $(\mathrm{ARP})$ of the Halimium halimifolium's essential oil.

\begin{tabular}{lcccc}
\hline & TAC $(\mathrm{mg} \mathrm{AA} / \mathrm{g})$ & IC50 $(\mathrm{mg} / \mathrm{mL})$ & EC50 $(\mathrm{mg} / \mathrm{mgDPPH})$ & ARP \\
\hline Essential oil & $708.37 \pm 0.94$ & $0.77 \pm 0.00$ & $32.20 \pm 0.02$ & $3.10 \pm 0.12$ \\
Standard quercetin & & $0.10 \pm 0.00$ & $0.04 \pm 0.00$ & $24.03 \pm 0.00$ \\
\hline
\end{tabular}

Mean value \pm standard deviation of three replicates is mentioned.

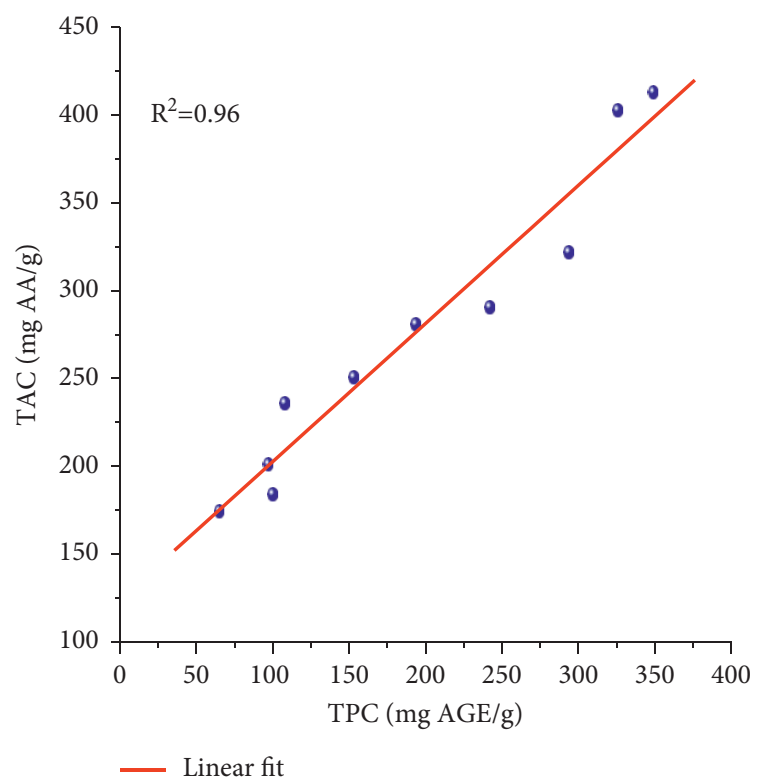

(a)

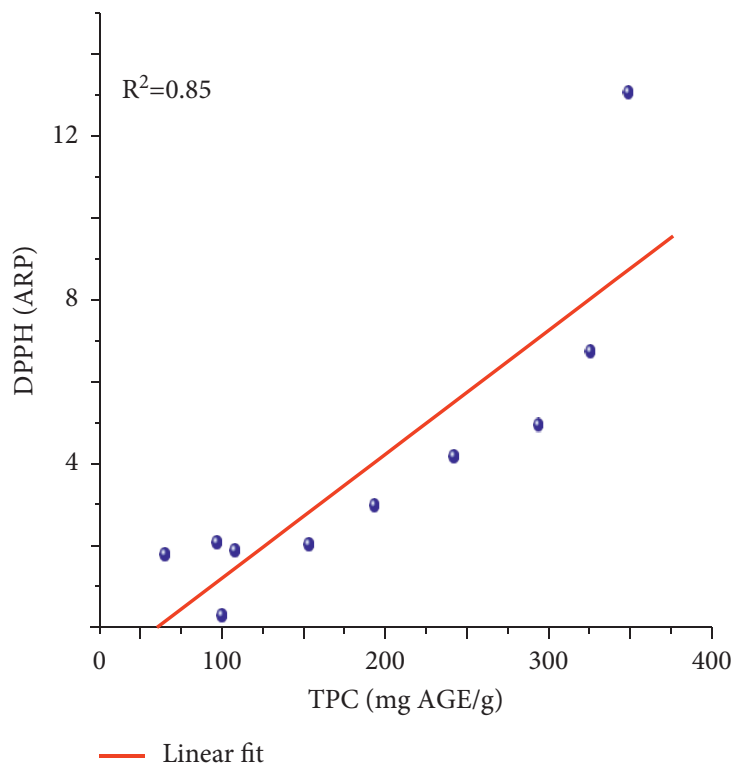

(b)

FIGURE 3: Linear dependency between the antioxidant activity TPC and DPPH assay.

extracts revealed the lowest total antioxidant activity and the antiradical power. The crude extracts of the Halimium halimifolium show an increase of TAC and ARP when the used solvent polarity during the extraction is increased too. Comparing our results with those obtained by Rebaya et al. [24] where the leaves of Halimium halimifolium harvested from Tunisia showed an increase in ARP (decreasing of $\mathrm{IC}_{50}$ ) when the solvent's extraction polarity increases too, except the ethanol which has showed the highest ARP, as well, the aqueous and the ethanol extracts showed greater antioxidant activities due to their highest polarities, followed by ethyl acetate and dichloromethane extracts. The results of Rebaya et al. [24] are similar to the results of this paper, where the
Halimium halimifolium harvested from Morocco showed antioxidant activities lower than those of Tunisian Halimium halimifolium which is may be related to the harvested regions' groundwater, climatic, or population differences. This study declared the huge potential of the leaves and stems of Halimium halimifolium and it is in compliance with the medicinal potential of Cistaceae family showed by several authors such as Zidane et al. and Enrique et al. [28, 29].

3.7. Antioxidant Activity of the Essential Oil. The phosphomolybdenum process and scavenging free radical DPPH assays were used to estimate the antioxidant activities of the 


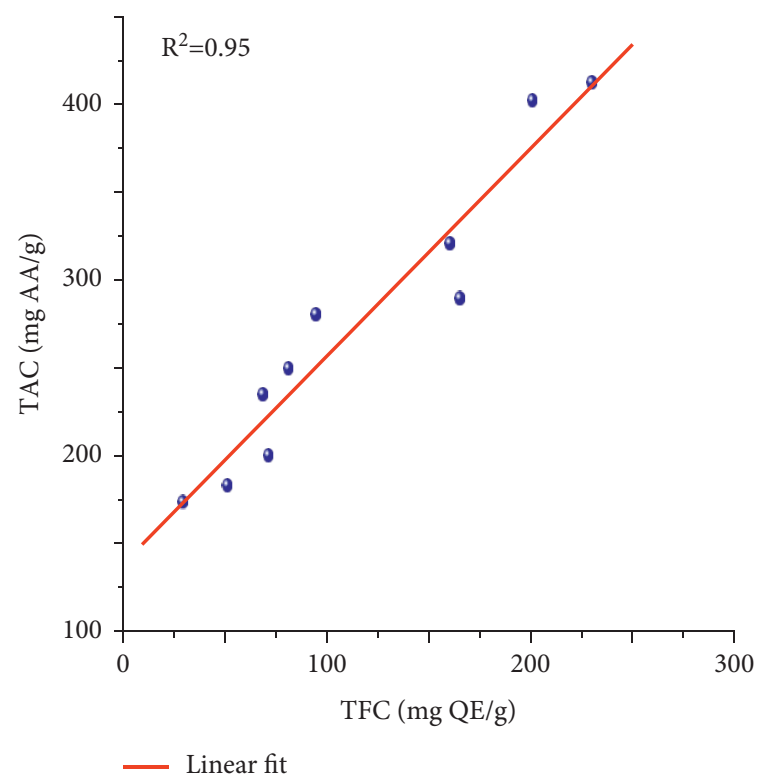

(a)

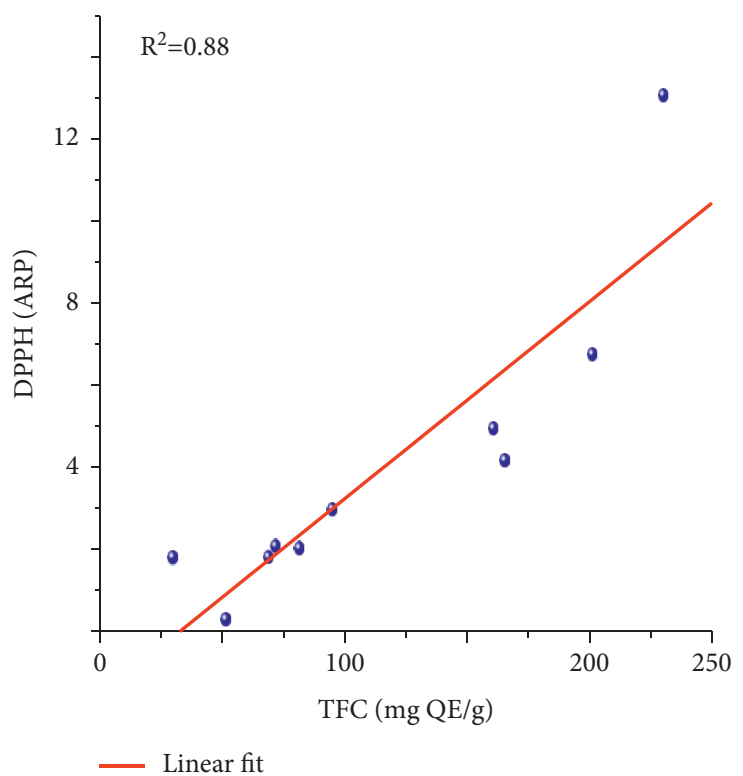

(b)

FIgURE 4: Linear dependency between the antioxidant activity TFC and DPPH assay.

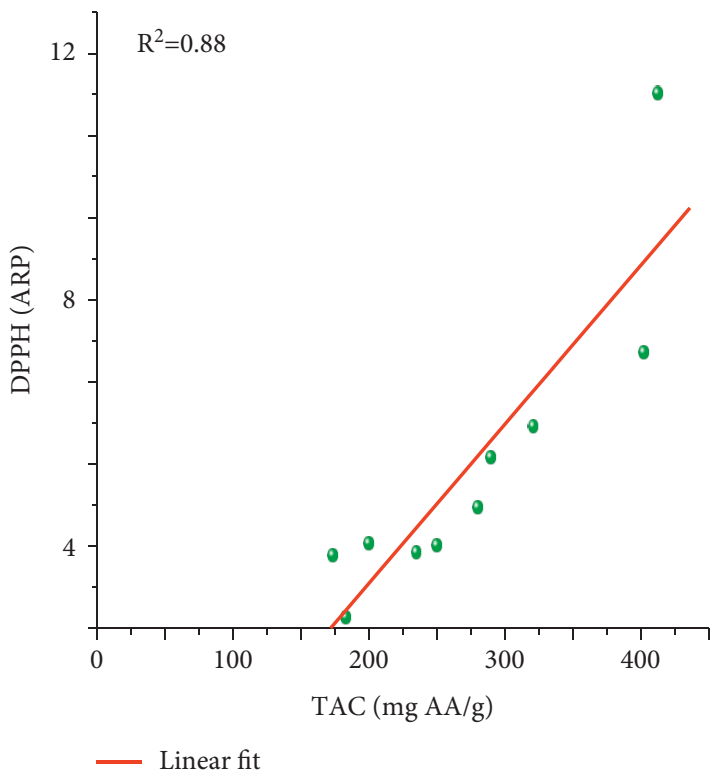

FIGURE 5: Linear dependency between the antioxidant activity TAC and DPPH scavenging activity.

Halimium halimifolium's essential oil (Table 7). Its TAC was stronger than the crude extracts' TAC, while its radical scavenging capacity presents less than $8 \%$ of the quercetin standard capacity. The mean value \pm standard deviation values of the three replicates are shown.

3.8. Correlation. During this study, using DPPH free radical scavenging and TAC assays, the addiction of antioxidant activities of the Halimium halimifolium crude extracts was calculated.
In Figure 3, we have plotted TAC and DPPH versus TPC in Figures 3(a) and 3(b), respectively. The results exhibit a significant positive correlation of TPC with TAC $\left(R^{2}=0.96\right)$ and with DPPH free radical scavenging $\left(R^{2}=0.85\right)$.

Figure 4 shows TAC and DPPH versus TFC in Figures 4(a) and 4(b), respectively. Important correlation is observed from the value of $R^{2}$; that is, TFC correlates positively with TAC $\left(R^{2}=0.95\right)$ and DPPH $\left(R^{2}=0.88\right)$.

Finally, Figure 5 illustrates DPPH as a function of TAC. It is also seen that TAC and DPPH present a significant positive correlation $R^{2}=0.88$. 
It is worthwhile to mention that the results show that the phenolic compounds positively influence the antioxidant activities. These results are similar to those of previous studies such as in $[3,30]$ in which the results confirm that an aromatic plant's phenolic content may be the major contributor of the antioxidant activities.

\section{Conclusion}

The aim of this study is to investigate the Halimium halimifolium's extracts and its essential oil. Using the physicochemical characteristics, the control of the quality of the Halimium halimifolium's essential oil served to highlight this essential oil's quality which is distinguished by the low values of the acidity and the ester indexes. It is also found that the essential oil revealed the greatest antioxidant capacities. Moreover, the use of different polar solvents has a great influence $(P<0.05)$ on the total phenolic compounds, the total flavonoids content, and the antioxidant activities of different parts of the Halimium halimifolium crude extracts. These results indicate that the leaves' aqueous extract of the Halimium halimifolium had the uppermost total phenolic and flavonoid concentrations and the greatest antioxidant capacities by the TAC and the DPPH assays. In addition, TFC and TPC correlated significantly with the antioxidant activities measured by DPPH radical and TAC assays. Therefore, these methods are suitable to evaluate the antioxidant capacities of the Halimium halimifolium. Based on results of this investigation, Halimium halimifolium is a potential source of new bioactive compounds which prohibit oxidative stress development. In order to assess the Halimium halimifolium's potential biological activities, this plant should be further investigated.

\section{Data Availability}

The authors confirm all data underlying the finding in this study are fully available without restriction.

\section{Conflicts of Interest}

The authors declare no conflicts of interest.

\section{Acknowledgments}

The authors acknowledge the common analysis center of the Faculty of Sciences, Moulay Ismail Morocco of Sciences, Moulay Ismail, Morocco.

\section{References}

[1] A. Shahid-Ud-Daula, A. Kamariah, L. Lim, and N. Ah- mad, "Phytochemical screening, antioxidant, and antimicrobial activities of leaves, stems, and rhizomes of etlingeracoccinea (blume) s. sakai nagam," International Journal of Pharmacognosy and Phytochemical Research, vol. 7, pp. 873-883, 2015.

[2] T. Grune, R. Shringarpure, N. Sitte, and K. Davies, "Age related changes in protein oxidation and proteoly- sis in mammalian cells," Journal of Gerontology, vol. 56, pp. 459467, 2011.
[3] M. Barbouchi, K. Elamrani, M. El Idrissi, and M. Choukrad, "A comparative study on phyto- chemical screening, quantification of phenolic con- tents and antioxidant properties of different sol vent extracts from various parts of pistacialentiscus L," Journal of King Saud University Science, vol. 32, pp. 302-306, 2018.

[4] M. Zunzunegui, M. C. Díaz Barradas, and F. García Novo, "Different phenotypic response of Halimium halimifolium in relation to ground water availabil- ity," Plant Ecology, vol. 148, no. 2, pp. 165-174, 2000.

[5] M. Zunzunegui, M. C. Díaz Barradas, F. Aguilar, F. Ain Lhout, A. Clavijo, and F. García Novo, "Growth response of Halimium halimifolium at four sites with different soil water availabil- ity regimes in two contrasted hydrological cycles," Plant and Soil, vol. 247, no. 2, pp. 271-281, 2002.

[6] J. Clevenger, "Apparatus for the determination of volatile oil," Journal of the American Pharmacists Association, vol. 17, pp. 346-351, 1928.

[7] R. P. Adams, Identification of Essential Oil Compo- Nents by Gas Chromatography/Mass Spectrometry, Vol. 456, Allured publishing corporation, Carol Stream, IL, USA, 2007.

[8] A. Nacira and Y. Boughérara, "Activité Antimicrobi- enne de l'Huile Essentielle du Cyprès Vert $(\mathrm{Cu}$ - pressus sempervirens L)," Algerian Journal of Natu- ral Products, vol. 2, pp. 455-462, 2017.

[9] T. Gutfinger, "Polyphenols in olive oils," Journal of the American Oil Chemists' Society, vol. 58, no. 11, pp. 966-968, 1981.

[10] V. Goulas, V. Exarchou, L. Kanetis, and I. P. Gerothanassis, "Evaluation of the phytochemical content, antioxidant activity and antimicrobial properties of mountain tea (Sideritis syriaca) decoction," Journal of Functional Foods, vol. 6, pp. 248-258, 2014.

[11] A. Olajire and L. Azeez, "Total antioxidant activity, phenolic, flavonoid and ascorbic acid contents of nigerian vegetables," African Journal of Food Sci- ence Technology, vol. 2, pp. 22-29, 2011.

[12] P. Prieto, M. Pineda, and M. Aguilar, "Spectrophotometric quantitation of antioxidant capacity through the formation of a phosphomolybdenum complex: specific application to the determination of vitamin E," Analytical Biochemistry, vol. 269, no. 2, pp. 337-341, 1999.

[13] M. N. Alam, N. J. Bristi, and M. Rafiquzzaman, "Review on in vivo and in vitro methods evaluation of antioxidant activity," Saudi Pharmaceutical Journal: SPJ: the official publication of the Saudi Pharmaceutical Society, vol. 21, pp. 143-152, 2013.

[14] T. Masuda, S. Yonemori, Y. Oyama et al., "Evaluation of the antioxidant activity of environmental plants: activity of the leaf extracts from seashore plants," Journal of Agricultural and Food Chemistry, vol. 47, no. 4, pp. 1749-1754, 1999.

[15] S-M-C, "Methods used to evaluate the free radi- cal scavenging activity in foods and biological sys- tems," International Journal of Food Science and Technology, vol. 8, pp. 121-213, 2002.

[16] S.-Y. Wang, J.-H. Wu, L.-F. Shyur, Y.-H. Kuo, and S.-T. Chang, "Antioxidant activity of abietane-type diterpenes from heartwood of taiwania cryptomerioides hayata," Holzforschung, vol. 56, no. 5, pp. 487-492, 2002.

[17] G. T. Kroyer, "Red clover extract as antioxidant active and functional food ingredient," Innovative Food Science \& Emerging Technologies, vol. 5, no. 1, pp. 101-105, 2004.

[18] C. Kanko, B. E.-H. Sawaliho, S. Kone, G. Koukoua, and Y.T. N’Guessan, "Étude des propriétés physico-chimiques des huiles essentielles de Lippia multiflora, Cymbopogon citratus, 
Cymbopogon nardus, Cymbopogon giganteus," Comptes Rendus Chimie, vol. 7, no. 10-11, pp. 1039-1042, 2004.

[19] T. Okudu, T. Yoshida, and T. Hatano, "Chemistry and antioxidative effects of phenolic compounds from licorice, tea and Compositae and Labiateae herbs," Food phytochemicals for cancer prevention, vol. II, pp. 132-143, 1994.

[20] B. Tepe, M. Sokmen, H. A. Akpulat, and A. Sokmen, "Screening of the antioxidant potentials of six Salvia species from Turkey," Food Chemistry, vol. 95, no. 2, pp. 200-204, 2006.

[21] A. Crozier, H. Ashihara, and M. N. Clifford, Plant Sec- Ondary Metabolites: Occurrence, Structure and Role in the Human Diet, pp. 1-24, Blackwell Publishing, 2006.

[22] M. Özcan, "Characteristics of fruit and oil of tere- binth growing wild in Turkey," Journal of the Science of Food and Agriculture, vol. 84, pp. 517-520, 2004.

[23] M. Özcan, O. Tzakou, and M. Couladis, "Essential oil composition of the turpentine tree fruits growing wild in Turkey," Food Chemistry, vol. 114, pp. 282-285, 2009.

[24] A. Rebaya, S. Belghith, B. Baghdikian et al., "Total phenolic, total flavonoid, tannin content, and antioxidant capacity of Halimium halimifolium (Cistaceae)," Journal of Applied Pharmaceutical Science, vol. 5, pp. 52-57, 2014.

[25] F. Q. Alali, K. Tawaha, T. El-Elimat et al., "Antioxidant activity and total phenolic content of aqueous and methanolic extracts of Jordanian plants: an ICBG project," Natural Product Research, vol. 21, no. 12, pp. 1121-1131, 2007.

[26] A. Zitouni, N. Belyagoubi-Benhammou, N. Ghembaza, F. Toul, and F. Atik-Bekkara, "Assessment of phytochemical composition and antioxidant properties of extracts from the leaf, stem, fruit and root of pistacialentiscus," Int. J. Pharmacogn. Phytochem. Res, vol. 8, pp. 627-633, 2016.

[27] C. M. Galanakis, V. Goulas, S. Tsakona, G. A. Manganaris, and V. Gekas, "A knowledge base for the recovery of natural phenols with different solvents," International Journal of Food Properties, vol. 16, no. 2, pp. 382-396, 2013.

[28] H. Zidane, M. Elmiz, F. Aouinti F et al., "Chemical composition and antioxidant activity of essential oil, various organic extracts of Cistus ladanifer and Cistus libanotis growing in Eastern Morocco," African Journal of Biotechnology, vol. 12, pp. 5314-5320, 2013.

[29] B. C. Enrique, FA. Salvador, S. Domingo et al., "Cistaceae aqueous extracts containing ellagitannins show antioxidant and antimicrobial capacity and cytotoxic activity against human cancer cells," Food and Chemical Toxicology, vol. 48, pp. 2273-2282, 2010.

[30] G. Botsaris, A. Orphanides, E. Yiannakou, V. Gekas, and V. Goulas, "Antioxidant and antimicrobial effects of pistacia lentiscus L. extracts in pork sausages," Food Technology and Biotechnology, vol. 53, pp. 472-478, 2015. 